\title{
French jubilant but British equivocal after Ariane success
}

\section{Paris}

THE successful launch of Ariane 3 in the small hours of 16 September, after a 16month interruption, caused unrepressed jubilation in France, but restrained applause in Britain. This was not simply a question of Latin ebullience and English reserve. Whereas France is committed to a long-term European space programme and stands to profit from Ariane's success, Britain's role is becoming minimal, following government refusals to provide money for a bigger stake (see Nature 328, $565 ; 1987)$.

Ariane has been out of service since its V18 flight was aborted seconds after liftoff in May 1986, due to ignition problems in the third-stage cryogenic motor. With these problems overcome. Arianespace, the company set up by the European Space Agency (ESA) to market and operate Ariane, becomes the only western company able to offer commercial satellite launches. This lead will only last until 1991, when the backlog of orders, worth $£ 1.500$ million, should have been cleared and when other competitors present more of a threat.

The Americans have been out of the running since the Challenger shuttle disaster and problems with their conventional launchers last year. US companies manufacturing Thor Delta and Titan rockets have recently been revived by large orders from the US Air Force and will undoubtedly wish to use the technology to compete in the commercial sector, particularly following the recent successful launches of Chinese, Soviet and Japanese rockets.

To keep its position in space into the next decade, ESA therefore needed to restore Ariane's credibility as a reliable commercial launcher. This assurance was not so much for Arianespace's customers, whose oustanding orders are already partly paid for, but to convince sceptical ESA members that extension of Europe's space programme is not throwing good money after bad. At a crucial ESA ministerial meeting to be held in The Hague in November, members will be asked to commit themselves to Europe's 'Colombus' contribution to the proposed $\$ 18,000$ million US National Aeronautics and Space Administration (NASA) space station (see Nature 329, 4; 1987).

With a 60 per cent stake in Arianespace, compared to Britain's 2.4 per cent, France has the most to lose if Columbus does not get the necessary backing. Part of the Colombus programme, the next generation of Ariane 5 rockets would be used to launch the controversial French Hermes shuttle.

A shadow was cast on plans for the Colombus programme to link up with the NASA space station when ESA and NASA failed to agree on fundamental terms of reference at a meeting in Frascati, Italy last week. The United States, the major financial backers, want overall control of the station and an option to use it for military research, both vigorously contested by ESA delegates.

Mrs Thatcher's unwillingness to support the $£ 200$-million British National Space Centre (see right) has also provoked questions in ESA regarding Britain's commitment. With Ariane's success there is now a growing feeling that Britain's contribution, while welcome, is not essential.

\section{UK industry's late space bid}

\section{London}

WITH barely 6 weeks remaining before ministers from the 13 member states of the European Space Agency (ESA) meet in The Hague to decide on the next suite of European space programmes, Britain's commercial space community is making last-ditch attempts to persuade the government to reverse its decision not to increase investment in space research. Hopes are being pinned on the government's newly formed Advisory Council on Science and Technology (ACOST), which will meet on 29 September. One of ACOST's functions is to advise the government on "the nature and extent of United Kingdom participation in international collaboration in science and technology".

The ESA summit is expected to ratify three main programmes over the next decade, needing at least a doubling of the present annual budget of $£ 1,000$ million. Because of ESA's strict industrial returns rule, member states receive contracts in proportion to their contribution to the budget. Britain has a 12 per cent stake in ESA. In July the prime minister, Mrs Margaret Thatcher, announced that the government's £112-million space budget would not increase "for the time being".

Last week, Britain's industrial space community stepped into the fray with the formation of a new company called Space Ventures Ltd, whose main objective "the promotion, for the benefit of the United Kingdom, of the opportunities arising from the exploitation of space".

Initially the company is being supported by British Aerospace, Marconi Space Systems, Logica, Westland Aerospace and Smith Associates. The company proposes to act as a link between technology suppliers, the government's British National Space Centre and financial institutions. The organizers will try to show the government that industry can provide more support for national space programmes.

In addition, the UK Industrial Space Committee has produced a booklet entitled British Industry in Space - a Time for Decision, which emphasizes the importance ot the economy of publicfunded space research, and says that for Britian to maintain its current position within ESA, national expenditure would need to be increased to $£ 250$ million annually over the next 3 years - less than 4 per cent of the government's research and development budget.

Opinion is divided over whether, after the ACOST meeting, any extra funds will appear and, if so, whether it will be too soon before the ESA meeting on 9 and 10 November to make any difference.

Simon Hadlington 